\title{
TV/Series
}

Hors séries 1 | 2016

Lost: (re)garder l'île

\section{Lost: A Kaleidoscopic Fiction}

Claire Cornillon

Translator. Chloe Farrell

\section{OpenEdition}

\section{Journals}

Electronic version

URL: http://journals.openedition.org/tvseries/4958

DOI: 10.4000/tvseries.4958

ISSN: 2266-0909

Publisher

GRIC - Groupe de recherche Identités et Cultures

\section{Electronic reference}

Claire Cornillon, «Lost: A Kaleidoscopic Fiction », TV/Series [Online], Hors séries 1 | 2016, Online since 01 December 2020, connection on 05 December 2020. URL : http://journals.openedition.org/tvseries/ 4958 ; DOI : https://doi.org/10.4000/tvseries.4958

This text was automatically generated on 5 December 2020

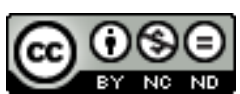

$T V /$ Series est mis à disposition selon les termes de la licence Creative Commons Attribution - Pas d'Utilisation Commerciale - Pas de Modification 4.0 International. 


\section{Lost: A Kaleidoscopic Fiction}

\section{Claire Cornillon}

Translation : Chloe Farrell

Lost (ABC, 2004-2010) never stopped questioning its own nature; it led the viewers to places they did not think they could go. Although at first glance it may seem possible to identify an evolution in the storyline of the show-from the fantastic into fantasy ${ }^{1}$ by means of science fiction-at the end of the day, its fictional universe has always been a world of fantasy. It is our perception of the series that shifted little by little with each season. Lost is a kaleidoscopic fiction because of its visible fragmentation and underlying, even subterranean, unity. Yet the show tells the story of a community as it is built, through the transformation of perspective. Thus, it is not a formalist game or enigma but an initiatory path-the experience of a mystery to which one must ultimately give in to make sense of the show.

\section{A Visible Evolution}

2 The question of how to define the fantastic, science fiction, and fantasy is complicated and a subject of hot debate. It seems to me that these three categories are a matter of approach rather than of genre. In my previous work, I proposed several criteria for differentiation ${ }^{2}$ that I will pursue further in this article. Nevertheless, the purpose of this article is not to affix labels of any sort. Rather, it is a matter of identifying three fictional modes to help us reflect on the way in which this television series functionswhich may be referred to as one wishes. Nevertheless, I will conserve the traditional categories of the fantastic, science fiction, and fantasy here and note what I maintain of these definitions, as there are direct references to the tradition of these genres mentioned in the series.

Indeed, Lost's narrative is punctuated by a variety of signs that distract from aspects of the series and that prove to be fundamental as time goes on-signs that nevertheless make appearances from the very beginning. Much like a magic trick, our attention is attracted to one spot to prevent us from seeing where the trick is actually taking place. The specificity of Lost is that it confronts us with the fact that we are looking in the 
wrong spot and thus deconstructs the illusion. To do so, it circulates a variety of signs and codes that can be attributed to different genres of the imaginary ${ }^{3}$-the fantastic, science fiction, and fantasy. These reference genres intermingle and are each present to varying degrees as the series goes on. Each time the show seems to settle into one of these genres, an exception becomes apparent, making the interpretation aporetic. A new perspective is thus created, changing the way in which we view the show. It is not so much that the show changes its genre, but rather that it purposefully misleads us before asserting its true identity.

4 The show's first red herring is without a doubt the "realist" narrative. Although it is surprising that there are survivors of a crash of that gravity, nothing of the show's beginnings hint at what is to come. It is only after the first twenty minutes of the pilot episode that the show takes a turn into the fantastic. Indeed, the characters begin to hear strange noises in the jungle that are difficult to identify. Some of the sounds have a metallic quality. Although the audience does not yet know it, these are the sounds of the Smoke Monster. The tops of the palm trees shake, as if an enormous creature were moving through them, leading to the question of whether a monster inhabits the island -a sort of King Kong figure of the modern era. At this point, it is a legitimate question to be asking. Yet no answer is offered. It is largely because of this uncertainty-this perfectly Todorovian ${ }^{4}$ hesitation-that anxiety manifests. Anxiety, as opposed to fear, results from an unknown or invisible threat, rather than from an imminent danger. The fantastic is founded on the appearance of a strange and supernatural element in our universe; this element becomes a cognitive obstacle, creating disruption in the fictional universe that functions either as hesitation or as state of shock. ${ }^{5}$

Starting in minute 20 of the pilot episode, various potentially supernatural elements appear. Their nature is unknown and their very existence is questionable. Most notably, this can be observed in the characters' visions-for example, Jack's visions of his dead father. It is impossible to determine if the visions are real, or if they are related to the character's past traumas. This is especially the case considering that within the narrative, these visions are always associated with specific moments from the past and the character's current journey. This hesitation between reality and hallucination is a recurring aspect of the fantastic. Moreover, the series draws upon musical and visual codes taken from genre films, fantastic cinema, and even horror films, which invite the audience to view the narrative through this lens. Indeed, the Smoke Monster is initially invisible because it is depicted in subjective camera or offscreen. Although the characters see it, the audience only perceives it in the terrified faces of the characters. This is a classic technique used in fantastic film and television, such as The X-Files (Fox, 1993-2002). Throughout Lost's first few seasons, certain sequences function as short films in the style of genre cinema. In this way, Jacob's cabin is based on the model of a haunted-house film. In the same vein, the plane pilot's death is filmed in the style of a monster film, in a scene meant to evoke Jurassic Park (directed by Steven Spielberg, 1993). This is done through rhythm: periods of waiting and then sudden violence-screams, terrified faces, an invisible threat, a camera whose frenetic movements imply panic, the blue filter, and ultimately the classic spray of blood on the window. The image is saturated with these codes; the first time watching the show, it is impossible to see anything else, as if Lost were setting up an initiatory trap for the audience. 
6 The first three seasons remain within the hesitation of the fantastic; yet as time goes on, there are an increasing number of unexplained elements that begin to join together to form a system. It clearly exists, despite the seeming impossibility of decoding it. Moreover, in the pilot episode, the first flashback occurs just after the noises in the forest introduce the uncanny. It thus creates a rift in the narration; its very existence indicates that greater challenges are in store beyond the crash itself. In this case, the crash is not simply a starting point for the plot of a horror film, but rather it constitutes an arrival point or a step along the way. As soon as a system presents itself, the genre is either that of science fiction or fantasy. Yet science fiction ultimately serves as another red herring. In this case as well, especially when it comes to season 4, various signs progressively change the interpretative paradigm. Some are anecdotal, such as when Locke gives to Ben the Philip K. Dick novel Valis. This is significant because the type of science fiction it references is part of a mystic and gnostic tradition that resonates with the spirit of the show. It is nevertheless a non-recurring detail. However, there are other significant details, such as the ever-increasing presence of the Dharma Initiative. The various Dharma stations serve as a recurring backdrop in the series-their logo permeating the screen. Moreover, Daniel Faraday takes on a sudden importance within the narrative and, in a way, begins to embody a sciencefictional approach toward the events in the show's narrative. Much like the members of the Dharma Initiative, Faraday uses a scientific approach to understand the events that occur around him, believing that he has an intellectual mastery over them. Ultimately, when all exterior indications of science fiction converge, season 4 focuses in on one of the genre's major themes: time travel. This theme makes its first appearance in S03E08 and the following episode is called "Stranger in a Strange Land"-the title of a classic work of science fiction from the 1960s, which again calls up the question of spirituality.

7 Yet, is the show truly a work of science fiction? In reality, one must wait for the conclusion of the show to understand that the show's approach is much closer to fantasy and that this means there is a different way of approaching the show's fictional elements that diverge from our universe. From this point on, certain questions become obsolete, because there are more pressing matters at hand. Indeed, in a work of fantasy, no one asks why the story features dragons, because they fit into the fictional universe. If Lost is a work of fantasy, there is no reason to question why the Man in Black is a monster composed of black smoke or why certain characters have special powers. In science fiction, however, this would be a fundamental question, because the fictional universe would be constructed in such a way that would allow these elements to exist, and these elements would be a founding principle of the construction of the fictional universe. In fantasy, what is going to be important are the symbolic interpretations that can be assigned to these elements and their adherence to a representational system or, potentially, to a value system, such as the opposition between the black of the Man in Black and Jacob's white.

8 Yet, in contrast with the way in which these elements are generally presented in fantasy, they are initially presented as problematic instead of as normal aspects of the fictional universe. From this point on, each time these successive categories appear, they imply the adoption of a specific perspective in relation to the same object. The survivors of the crash have a perspective that can be considered fantastic, because they live within the anxiety of the unknown; the members of the Dharma Initiative have a science-fictional perspective. The Others-as well as the survivors who have gained a 
certain knowledge of the island-have a perspective of fantasy. It is the perspective that changes rather than the object itself. In this way, the Man in Black is considered to be a "monster" by the majority of the characters, until Danièle Rousseau describes him as a "security system" in season 2 .

9 Through the lens of these changing perspectives, the show's use of these overarching genre categories is not a superficial game but rather resonates with the show's metafictional and metaphysical discourse. It is a question of changing the way we perceive the show by revealing the ways in which our perception is conditioned by certain expectations and preconceived ideas. As Pacôme Thiellement notes, "That is the gamble that Lost takes: transforming our way of being by transforming our way of watching-introducing contemporary human beings to a conscious relationship with the workings of the soul." ${ }^{6}$ When the audience begins to perceive the show as fantasy, it becomes clear that it has always been a work of fantasy. The use of archetype is present from the beginning and leads to a symbolic interpretation, especially when it comes to Locke's game of backgammon.

10 As a consequence, it is not surprising that Lost contains many metaphorical, almost parabolic, stories-especially when it comes to the depiction of animals (for example, the comparison between Charlie and the butterfly in S01E16). These elements function either as folklore or as myth. Myth becomes a key narrative device in the story surrounding Jacob and his brother.

11 In the last part of the show, the veil is lifted, and the conception of the island's geography-which was initially focused on survival and then on the map of the Dharma stations-is replaced by a conception that draws upon the sites of a much more ancient past: on mythical and sacred spaces such as the temple, the statue, the lighthouse, and, of course, the Heart of the Island. Three essential ways of conceptualizing the showthe mythic, the tragic, and the epic-come to the fore, emphasizing the show's most fundamental theme, namely, the idea of community and coexistence. All of the differences that create conflict among the characters stem from divergent ways of viewing the world and life itself. Although they may never completely align, they are ultimately able to coexist.

These forms of conceptualization offer a metaphorical means of reflecting upon the human condition at its most fundamental level, without falling into an essentialist portrayal of the struggle between Good and Evil. Instead, they illustrate the confrontation between two choices-two conceptions of human ontology-namely, those of Jacob and his brother. A pure conception of Good does not exist, because Jacob himself has already been corrupted by his crime. The most powerful and ancient characters, those who take on aspects of myth, are themselves defined by the events of their lives, which substitute the question of origins for an infinite past. This renewed focus on a distant past, which is nevertheless not the "origin," evokes a mythological prehistoric time. From then on, the guardian of the healing island, the immortal adviser, the medium who hears the dead, and the twin transformed into black smoke all have their places in an archetypal universe that represents-as in allegory-an arena in which the human condition plays out. In other words, we move from the jungle to the Dharma station, and from there, to the highly symbolic backdrop of the Temple. Rather than viewing the island's mysterious elements as gimmicks, they should be viewed as gateways to a space-time in which the actions of human beings and the events of the world are intensified. 
From this point on, the island functions as a microcosm in the image of the macrocosm. The island is a concept of totality that is simultaneously ancient, modern, scientific, and religious. The fact that various elements that appear off of the island operate in continuity with the rest-such as the trap door in season 2 or the village in season 3reinforces this idea of totality. Although we may believe that we are no longer on the island, we actually are. This concept of totality turns the island into an image in the fullest sense, meaning a space that is slightly misaligned with our day-to-day experience of the world, yet which-through this misalignment-is capable of shedding light on our experience.

\section{A Change in Perspective}

14 When one watches the show for a second time, one notices that the symbolic manner in which the narrative functions is present from the very beginning. In episode S01E05's opening scene, a flashback to Jack's childhood is followed by a scene on the island in which he attempts to save a drowning person. The person turns out to be Boone, who himself was trying to save a young woman. This scene is a prime example of the way in which the show functions. It offers up an initial reading (an initial person to save) but then presents a further problem (a second drowning person), which is concealed at first and will ultimately remain unresolved. Indeed, Jack is unable to save the young woman because he chooses to get Boone to safety first. As with many of the show's opening sequences, the absence of the supernatural and enigmatic elements of the island is striking. The opening sequence follows the character who will be the subject of the episode, establishing its thematic focus in relation to the character's psychological journey. In this case, it is Jack's ambivalence toward taking responsibility and action; he is a hero who believes that he cannot be a hero. This aspect of his personality is linked to his relationship with his father, which is revealed as the episode goes on. Thus, from the very beginning, the opening sequence highlights the initiatory path that the characters will take rather than the mysteries to be solved, although the main reactions to (and critiques of) the show have concentrated on the latter. The island is the physical representation of a symbolic space; it is by traveling through this symbolic space (the means) that the characters will be able to discover who they truly are (the end). More specifically, the island as a symbolic space represents the spiritual. The show illustrates the tension between two paths-the rejection of spirituality represented by the Man in Black and the omnipotence of spirituality represented by Jacob. Yet Lost establishes a third path that is represented most notably by Jack and Hurley: a more human spiritual middle ground, which places its emphasis on love.

The show unfolds like a tryptic in which season 1 and season 6 function in relation to each other. The first functions as a period of exposition and solitude, and the last as one of resolution and love. Seasons 2 to 5 are the seasons of the initiatory journey. This is an essential plot structure because it highlights the fact that the stakes of the show were established from the very beginning, even as the audience's attention was focused elsewhere. In a symbolic and reflexive gesture, Jack finds himself in the bamboo forest in the first scene of the pilot episode, next to the Heart of the Island, which he will find only at the end of the show, when he is ready to see it. When watching the show a second time, the audience knows enough to take the signs for what they are- 
superficial details, or even red herrings. Ultimately, the show's ending describes a world that is not one of enigma but one of mystery in the fullest sense of the term.

In the end, Lost does not operate through the dissemination of clues. In reality, the audience is tipped off to this fact multiple times in scenes that seem to be conceived for this purpose. The opening sequence in S03E07, "Not in Portland," is littered with clues that lead the audience to believe that the action is taking place on the island: the beach, the appearance of the hallway with the malfunctioning light, the record, Ethan, the dialogue in which the sister could seem to be talking about Ben, and the anxietyprovoking music that we associate with the Others. Yet in the final reveal, Juliet literally unveils the fact that it is Miami and thus, as Aurélie Villers ${ }^{7}$ notes, a flashback. The audience falls for the trick; they decipher what seem to be clues, but overlook Juliet's hairstyle-the most important detail-as it is the hairstyle she sports in flashbacks. In the microstructural gesture, the show demonstrates what we should not do when attempting to understand.

17 Lost often makes use of twists and didactic transformations of perspective. This is especially the case at the beginning of each season, as it is a key moment for the serial aspect of the narrative. In the opening sequence of season 2 therefore, a great effort is made to disorient the audience. Aside from the recurring close-up of the eye that opens the sequence, there are no details that allow the audience to identify the location, the moment in time, or the character. Not only is the information intentionally fragmented because Desmond is seen from behind and the many close-up shots make it impossible to establish a picture of the whole, but also, more than anything, the show presents a string of clues that serve as red herrings. The lamp and the records lead us to believe that the scene takes place in the 1970s, but when we arrive at the moment in which Desmond injects something into his arm, a certain strangeness is created, there is an explosion, and the music changes. This turn of events reestablishes Lost's identity, but in a shifted context that remains beyond comprehension. The final shot of the sequence features an unexpected camera movement; rather than being shot from Desmond's bodily perspective, a subjective camera shows us the scene through his eyes. Quite literally, the camera follows the light waves that his eyes capture as he looks through the scope, moves toward the reflective mirrors, and ends with what he ultimately sees. In a final twist, the audience becomes aware of not only the continuity between this opening scene and the final scene of the first season, but of also their simultaneity. The two scenes take place at the same moment in time but from two different vantage points-that of the group and that of Desmond. The beginning of each season involves starting over, meaning that it falls into a pre-established pattern while starting afresh. Lost does this by reinventing itself in unexpected ways. The show does not unfold in a linear manner but rather adds a layer to the plot elements already present. It is therefore not an accident that the opening scene of this season takes place underground, because it is a matter of excavating reality.

This way of going about things plays on the possibilities that the sequence before the opening credits offers in terms of decontextualization, because nothing in the episode -or more important, in the season-precedes it. The audience's job is thus constantly to readjust their thinking in relation to what they see on-screen. It is then a question of adopting a hermeneutic stance. One must attempt to interpret the signs that are given, even though the clues that would allow the audience to truly understand are not unveiled until the final twist. Indeed, the audience must travel this path in order to 
reach a further stage of understanding. In a similar way, through a camera movement that offers a spectacular shot and a perspective shift similar to that found in the opening sequences of seasons 2 and 3, the opening sequence of season 6 completely restructures what we thought we knew up until that point. This time, the camera sinks rather than moving upward, showing us the island submerged at the bottom of the ocean. This acts as the ultimate plot twist, a twist within a twist. We should not look upwards as suggested in S02E01 and S03E01, from vantage points that offer partially obscured views (as we seemingly always view from below that which remains elusive), but rather look down, which is to say, plunge deeper into what is already in front of us.

Therefore, the path that the show takes is an initiatory experience for the characters and for the audience alike. At one point or another, each character delves deep into hermeneutics, basing their views of the world on the interpretation of symbols. Yet all are ultimately mistaken. When we first meet Daniel Faraday, we have the impression that his character is highly knowledgeable, making it easy for us to assimilate his perspective. "I know what's happening," he says in S05E01. He then produces his notebook, saying that it contains everything that he learned from studying the physics of time, as well as everything he knows about the Dharma Initiative. Yet his perspective is simplistic-as is that of the Dharma Initiative itself. This is why he ultimately finds himself out of his depth. He will have to tell Charlotte as a child what he didn't want to admit to her and will even be killed by his own mother. The action he undertakes is thus a total failure, because these events unfold in a cognitive realm outside of his grasp. His viewpoint does not allow him fully to understand what is happening around him. Although the action he takes may sometimes be effective, this does not mean that its foundations are based in reality.

This is precisely what happens for audience members who rely too heavily upon clues. At the end of the show, this manner of understanding the narrative turns out to be impossible. It does not function in this context. The only solution is a change in perspective-in other words, to accept that the narrative does not fall into the category of science fiction. The challenge of the show is thus to free ourselves of what we have been conditioned to perceive. As soon as we accept a change in perspective, it becomes possible to truly experience the show. This does not mean rejecting all that came before. On the contrary, the path we have travelled is just as important as the end goal. Due to the fact that we experienced these multiple perspective shifts, this kaleidoscopic fiction, we are ultimately able to question that which we take for granted and that which we have been conditioned to perceive.

Echoes and narrative resonances are thus consistent elements of Lost. Time and time again, characters will make statements that the people they are talking to are not yet ready to hear and that they will not understand until much later. In this way, at the end of the season 5, Rose and Bernard sum up the show itself in a few short sentences. At this point, the audience naturally align themselves with Sawyer and Kate's perspective, both of whom are not (yet) capable of understanding the significance of Rose and Bernard's discourse. Yet this scene anticipates-from very early on-the show's final moments. This is what Bernard says in S05E16: "So, we die. All we care about is being together. It's all that matters in the end." It is only much later that the other survivors will come to grasp what Rose and Bernard have already understood. 


\section{A Show of Togetherness}

In fact, the characters will construct an after-world for themselves-a space outside of time in which they can find each other after death. In the end, being together is what counts. This is why the show is fundamentally a show of togetherness, not only in the juxtaposition of the paths travelled, but also in the construction of the group and the relationships that form as the seasons go by. Not only do the flashbacks in the first seasons reveal the innumerable links between characters even before they meet, as is the case with Jacob's tapestry, but also once they have arrived on the island, friendship and love are at the center of the plot. Much like a soap opera (or a Shakespearian romance, as illustrated by Sarah Hatchuel and Randy Laist), Lost presents constant plot twists-the discovery of unknown family ties, love triangles, and never-ending drama. Ultimately, we must examine the link at play in the show between fantasy and melodrama. In the context of fantasy, the essential and culminating aspects of melodramatic storylines will gain importance and take on a certain universality. It is this aspect that ultimately leads to the show's culminating point. From the beginning, it is obvious that the plot will be focused on the relationships of the characters as much as-if not more than-on the construction of the show's mythology (because the mythology is based on the very idea of love itself).

From the start, there is an ever-increasing number of dramatic scenes in the show, notably at the ends of the episodes-scenes without dialogue accompanied by Michael Giacchino's music, scenes on the beach that show people coming together, or moments of exchange between life and death, such as in the paradigmatic sequence in which Boone's death occurs in conjunction with Aaron's birth. Sarah Hatchuel notes the following:

Because one of the show's essential themes is that of redemption through a community formed by common suffering, shared joy, mourning, solidarity, friendship, and love, Lost presents a meditation on the meaning of "coexistence," the bonds that join individuals together, and the construction of identity and otherness ${ }^{8}$.

The path of the characters and the audience involves "letting go," which is to say, accepting that we must give up some control in order to experience both the fiction and the world. The way in which the flashbacks function reflects this idea. One of the essential principles of video editing is the assumption of relevance: the brain draws links, notably causal links, between the scenes that we are presented. It is in this manner that we have learned to analyze images and create meaning. The flashbacks are thus naturally perceived as explanations of the events in the main narrative. Yet one of the show's main objectives is to render causal associations impossible, meaning not only to reject determinism but also to free itself from its influence. There is a new structure at work here, which takes place in three separate temporalities. The first is that of flashback, meaning the hyperdeterminism of the past that acts as a weight haunting the present. Next are the flash-forwards, in which the perspective is inverted and the main storyline becomes the past that haunts the characters in the future (making Jack want to go back to the island). Finally, season 6 introduces a third temporality, in which the scenes suddenly lose their causal links with the main storyline, so much so that we begin to conceptualize a flash-sideways-a parallel reality disconnected from the central narrative. In reality, it is a flash-ahead to a space outside of time in which the characters are destined to meet after their deaths. This is indeed 
the season of "letting go." All of the action leads to this moment, freed of the weight of endured necessity.

The flash-aheads come together to form a world that is built by the characters-a world in their image. It is thus a matter of perspective. It is not that the element of tragedy is absent (Locke is paralyzed, Charlie is addicted to drugs, Jack's father is dead) or that suffering no longer exists. Far from it. Rather, it is just a question of a difference in perception-of acceptance and coexistence. At the end of the show, Christian Shepard phrases it as "to remember and let go." To do so, one must experience a true connection with the other through shared emotion. This is the meaning of the anamnesis that punctuates the conclusion of the show. In the moment in which the characters are ready, the anamnesis represents the moment in which they take charge of their lives and reinvest in their own paths. It is a sort of return, except with a new sense of calm. Instead of knowledge, it is acceptance that is highlighted-the moment in which two characters recognize each other, in which they rediscover their own identities by coming into contact with the other, in a literal illustration of the expression "to remember and let go."

Lost shows us that even if it may not be possible to know all the facts, it is always possible to love. Ultimately, love gives us access to a form of superior truth, whether it is through romance, friendship, or the universal love represented by Hurley, who loves and helps everyone. It is therefore not random that he ends up as the protector of the island. The essential and existential issue at stake in Lost is this recognition. The scene in which Ilana tells Ben, "I'll have you" (S06E07) establishes this dynamic; she officially accepts him into the group. Lost's paradoxical construction-which is both highly complex and intellectual while still being centered on emotion-is resolved in this manner. The structure itself leads us to understand the possibilities of a human life. We had to give in to the mystery and enter allegory and fiction. We had to lift the barriers one by one and discover the different aspects of the image, to understand the complexity and simplicity within. We had to change our perspective, taking a second look at both the show and our own lives ultimately to see them in a new light. All of the complexity of the show's overarching purpose is resolved within the simplicity of a fundamental form linked with myth, the marvelous, empathy, and coexistence. The task that Lost undertakes is typical of seriality, because it is based not on the entry into fiction, but on repetition, variation, and more than anything, on the return. It is not a question of beginning, but of giving oneself the opportunity-at least symbolically-to begin again. It is a question of seizing the opportunity-regardless of where it is that we begin-to see in a new way.

\section{BIBLIOGRAPHY}

CORNILLON Claire, Par-delà l'infini, La spiritualité dans la science-fiction française, anglaise et américaine, Thèse de doctorat en Littérature comparée, sous la direction de Jean Bessière, Université Paris 3 - Sorbonne nouvelle, 2012, https://tel.archives-ouvertes.fr/tel-00869974 
HATCHUEL Sarah, Lost : Fiction vitale, Paris, Presses universitaires de France, 2013.

MELLIER Denis, L'Ecriture de l'excès, Fiction fantastique et poétique de la terreur, Paris, Champion, 1999.

THIELLEMENT Pacôme, Les Mêmes yeux que Lost, Paris, Léo Scheer, 2011.

TODOROV Tzvetan, Introduction à la littérature fantastique, Paris, Points, 2015 [1970].

VILLERS Aurélie, "Récits analeptiques et distanciation cognitive temporelle dans la série Lost", communication présentée au colloque de Cerisy "Comment rêver la science-fiction à présent ?", 2009.

\section{NOTES}

1. This article deepens the reflection that I proposed in an article written for the cultural website lintermede.com in 2009: http://www.lintermede.com/series-lost-jj-abrams-damon-lindelofjeffrey-lieber.php

2. See also: Claire Cornillon, Par-delà l'infini, La spiritualité dans la science-fiction française, anglaise, et américaine, a doctoral thesis in comparative literature, under the direction of Jean Bessière, Université Paris 3 - Sorbonne nouvelle, 2012, https://tel.archives-ouvertes.fr/tel-00869974

3. In French, "l'imaginaire".

4. See also Tzvetan Todorov, Introduction à la littérature fantastique, Paris, Points, 2015 [1970].

5. For more about the fantastic elements of shock, see also Denis Mellier, L'Ecriture de l'excès, Fiction fantastique et poétique de la terreur, Paris, Champion, 1999.

6. Pacôme Thiellement, Les Mêmes yeux que Lost, Paris, Léo Scheer, 2011, p. 53. My translation.

7. Aurélie Villers, "Récits analeptiques et distanciation cognitive temporelle dans la série Lost ", presentation given at the conference at Cerisy "Comment rêver la science-fiction à présent?", 2009.

8. Sarah Hatchuel, Lost: Fiction vitale, Paris, Presses Universitaires de France, 2013, p. 95. My translation.

\section{ABSTRACTS}

Lost seems at first to present an evolution from the fantastic to fantasy, through science fiction, but eventually reveals a didactic pattern that invalidates a series of cognitive hypotheses and viewpoints on the series. In fine, acceptance is more important in Lost than knowledge: rather than an enigma, the series is a mystery that we have to accept and an experience of a community of love and acceptance.

Lost semble, à première vue, présenter un glissement générique du fantastique à la fantasy, en passant par la science-fiction mais révèle finalement un fonctionnement didactique qui invalide une série d'hypothèses cognitives et de modes de lecture de la série. In fine, c'est la reconnaissance plus que la connaissance qui semble au cœur de la série : plutôt qu'une énigme, la série est un mystère qu'il faut accepter et qui confronte à l'expérience d'une communauté d'amour et d'acceptation. 
INDEX

Keywords: Lost, narration, genre, science fiction, fantastic, fantasy, codes

Mots-clés: Lost, narration, genre, science-fiction, fantastique, fantasy, code

\section{AUTHORS}

\section{CLAIRE CORNILLON}

Claire Cornillon has a PhD in comparative literature and a master in film studies. She teaches at the Université Paul Valéry-Montpellier 3. Her latest research aims at studying fiction and narration in American TV series, especially network series. She is general co-editor of the « Sérial » collection published at the Presses Universitaires François Rabelais.

Claire Cornillon est docteur en littérature comparée. Elle est également titulaire d'un master en études cinématographiques. Elle est actuellement PRAG à l'Université Paul Valéry-Montpellier 3. Ses recherches les plus récentes portent sur la narration et la fiction dans les séries télévisées américaines, en particulier de network. Elle co-dirige la collection Sérial aux Presses Universitaires François Rabelais. 